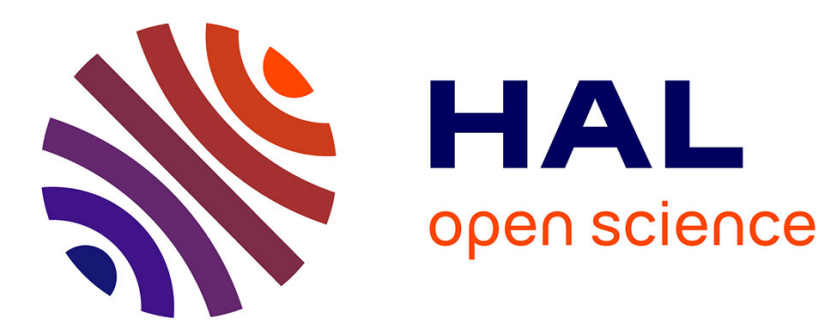

\title{
Leibniz and Descartes
}

Jean-Pascal Anfray

\section{To cite this version:}

Jean-Pascal Anfray. Leibniz and Descartes. Steven Nadler, Tad M. Schmaltz, and Delphine AntoineMahut. The Oxford Handbook of Descartes and Cartesianism, Oxford University Press, 2019, 10.1093/oxfordhb/9780198796909.013.45 . halshs-03183725

\section{HAL Id: halshs-03183725 https://shs.hal.science/halshs-03183725}

Submitted on 28 Mar 2021

HAL is a multi-disciplinary open access archive for the deposit and dissemination of scientific research documents, whether they are published or not. The documents may come from teaching and research institutions in France or abroad, or from public or private research centers.
L'archive ouverte pluridisciplinaire HAL, est destinée au dépôt et à la diffusion de documents scientifiques de niveau recherche, publiés ou non, émanant des établissements d'enseignement et de recherche français ou étrangers, des laboratoires publics ou privés. 
(Forthcoming in the Oxford Handbook to Descartes and Cartesian Philosophy, Delphine Antoine-Mahut, Steven Nadler and Tad Schmaltz (eds.) (Oxford, New York: Oxford University Press

Please do not cite without permission.)

\section{Leibniz and Descartes}

Jean-Pascal Anfray (Ecole Normale Supérieure, PSL)

Abstract: This chapter examines Leibniz's complex relation to Descartes. These relations are deeply influenced by the evolution of the intellectual context from the early 1670 's to the early $18^{\text {th }}$ century. Beyond Leibniz's overall appraisal of Descartes's philosophy, three areas stand out in which the discussion and criticism of Descartes's ideas played a decisive role in the development Leibniz's thought: epistemology, natural philosophy and philosophy of mind. There are three central issues at stake between the two philosophers: the nature and role of evidence, the use of final causes and the Law of continuity.

Keywords: Consciousness; Continuity (Law of); Evidence; Final Causes; Force; Motion (Laws of).

Gottfried Wilhelm Leibniz (Leipzig, 1646-Hanover, 1716) never was a Cartesian. Among his contemporaries, Hobbes and Spinoza arguably exerted a deeper influence on his thought. And yet, he was deeply and constantly engaged in a critical dialogue and controversies with Descartes's philosophy and Cartesianism. How critical he was toward Descartes depends on one's point of view. By the end of the seventeenth century, French 
Cartesians tended to see him as an opponent. Thus in 1697, Pierre-Sylvain Régis complains that "it has been clear for a long time that Monsieur Leibniz wants to build his reputation on the ruins of that of Mr. Descartes" (GP IV.333). In reply, Leibniz pledges innocence and grants that, "far from wanting to ruin the reputation of this great man, I find that his true merit has not been acknowledged" (GP IV.337). He concludes with a metaphor he regularly associates with Descartes: "I usually say that Cartesian philosophy is like the antechamber of truth" (GP IV.337; see also Letter to Christian Philipp, December 1679, A II.1.767/L 272; and the Letter to Nicolas Rémond, 10 January 1714, GP III.607/L 655). The metaphor is deliberately ambivalent: while acknowledging the importance of Descartes's views, Leibniz untiringly stresses either their deficiencies, as with his rules of method or his account of mind-body interaction; their indebtedness to predecessors, as in the case of the laws of optics and the principle of inertia; or their dangerous consequences in ethics and religion, as with the dismissal of final causes in physics. In the following, I begin by sketching the general development of Leibniz's attitude with respect to Descartes (section 1). I then highlight issues in three specific domains: method and epistemology (section 2); natural philosophy, the nature of bodies and their laws (section 3); and the nature of mind and the problem of the souls of animals (section 4). ${ }^{1}$

\section{The Development of Leibniz's Relation to Descartes's Philosophy}

Leibniz was not acquainted with Descartes's works in his early years. In a letter to Foucher dated 1675 , he admits that 
I have not yet been able to read all [Descartes's] writings with all the care I had intended to bring to them, and my friends know that, as it happened, I read almost all the new philosophers before reading him. Bacon and Gassendi were the first to fall into my hands ... Yet what I know of Descartes's metaphysical and physical meditations is almost entirely derived from reading a number of books, written in a more familiar style, that report his opinions (A II.1.388-9/AG 2-3).

The philosophical education Leibniz received in Leipzig, Altdorf and Iena was dominated by a kind of eclectic Reformed Aristotelianism. This did not prevent him from reading some of the moderns (moderni), Bacon, Gassendi and Hobbes in particular. In a letter to Jakob Thomasius, Descartes is cited as one of those moderni, alongside Patrizzi, Telesio, Galileo, Sennert, Digby and some others (A II.1.24/L 94). But at the time, his knowledge of Descartes was almost entirely second-hand. In the same letter to Thomasius, he mentions a list of Cartesian commentators, some of whom he may have read: Clauberg, De Raey, Clerselier, Hereboord, Andreae, Regius (A II.1.25/L 95). Leibniz adds that, while he adheres to the mechanist program of explaining everything in terms of size, figure and motion, he is nevertheless "anything but a Cartesian" (A II.1.24/L 94).

During his stay in Paris (1672-1676), however, Leibniz was introduced to Cartesian circles. But even there, his knowledge of Descartes remained largely indirect until the last year of his stay, when he began to read Descartes's writings extensively and carefully, especially the Principia, on which he wrote a first set of critical remarks in 1675 (A VI.3.213-7). Moreover, through Clerselier, he had access to Descartes's manuscripts in 1676 and made excerpts from them. ${ }^{2}$ Retrospectively, Leibniz stresses that his late reading of his works prevented his being subdued by Descartes's doctrines: 
I am unsure whether I was lucky to come late to the reading of this famous author (Descartes). I read him carefully only at a time when my mind was already filled with my own thought. Thus I believe I took advantage of his, without subduing myself to them (ca. 1698, Vorausedition to A VI.5, N.2065).

However, after this initial reading phase, Leibniz's writings on Descartes are almost always critical. The reaction to Spinoza's philosophy played a decisive role. On his way from Paris to Hanover, Leibniz visited Spinoza in The Hague, where he discussed his philosophy and also Descartes's. Although interpreting the role and influence of Spinoza's philosophy on Leibniz is a highly controversial matter, he clearly distanced himself from Spinoza's metaphysical views in 1678 , after reading his Opera posthuma. ${ }^{3}$ Thereafter, Leibniz constantly claims that Spinoza's philosophy is the logical consequence of some doctrines held by Descartes, or, as he puts it in a writing on Spinoza from the 1700s: "Spinoza begins where Descartes leaves off: in naturalism" (Leibniz 1854: 48/AG 277). Naturalism designates any view that conceives of God as an infinite power, acting necessarily, without regard for independent values of truth and goodness ${ }^{4}$.

The insinuation that Descartes's philosophy results in naturalism appears in the late 1670 s and remains remarkably stable over the following years, either in private papers and notes or in public writings and controversies. It forms the central thrust of a series of intertwined objections to Descartes, which are rehearsed with a remarkable constancy in several writings (Letter to ? 1679, A II.1.775-82/AG 240-5; Letter to Malebranche, A II.1.717-27/L 210; Letters to Christian Philipp, A II.1.786-9/L272-3; A VI.4.1389, 1475-8, 2045, 2051-2, 2064). 
A good representative is a short piece written in the early to mid-1680s, entitled "De la philosophie cartésienne”, where Leibniz lists a series of points on which he disagrees with Descartes (A VI.4.1479-88). The first three points relate to naturalism (A VI.4.1481-82): Descartes endorses the doctrine of the creation of the eternal truths (hereafter CET; see Sixth Replies, AT VII.431-3/CSM II.291-2; AT VII.435-6/CSM II.293-4). Second, he rejects final causes in physics (see Principles of philosophy I.28; AT VIIIA.15-6/CSM I.202-3). Finally, his claim that matter successively takes on all possible forms entails that no possibility remains unrealized. In a word, "Descartes's God, or perfect being, is not a God like the one we imagine or hope for, that is a God, just and wise, doing everything possible for the goof of creatures" (letter to ?, 1679, A

\section{II.1.778/AG 242).}

The three claims are deeply interconnected. CET entails that there is no objective standard of perfection and goodness. But if this is so, then God acts in a purely arbitrary manner, which amounts to the same as saying that the world stems from a blind causal power, excluding final causes. As Leibniz argues in a letter to Christian Philipp, dated January 1680:

For what kind of a will $[\ldots]$ is that which has not the Good as object or motive ? What is more this God will not even have understanding. For if truth itself depends only on the will of God and not on the nature of things $[\ldots]$ the understanding of God will be before the truth of things and consequently will not have truth for its object. [...] [C]onsequently it will be necessary to conceive God, after the manner of Spinoza, as a being who has neither understanding nor will [...] But to say that such a God has made things, or to say that they have been 
produced by a blind necessity, the one, it seems to me, is as good as the other (A II.1.788-9/Leibniz 1890: 4; see also DM, art. 2, A VI.4.1532-3).

Thus the denial of objective values entails the rejection of final causes and necessitarianism. The reverse entailment from necessitarianism to the denial of final causes holds as well. ${ }^{5}$

While CET and the exclusion of final causes in physics are well-documented doctrines in Descartes, the imputation of necessitarianism looks odder at first sight. Leibniz bases his reading on an almost single, isolated passage in Principles III.47, where Descartes claims that whatever the hypothesis concerning the initial state of the world, it would finally reach its actual state, since the world obeys laws of nature and "by the operation of these laws, matter must successively assume all the forms of which it is capable" (AT VIIIA.103/CSM I.258). The exact meaning of this passage is controversial, but Leibniz took it as entailing the necessity of all changes in the material world, from which it is a short step to infer a generalized necessitarianism.

In addition, Leibniz charges Descartes with the ambition of founding a sect in which the Cartesians are mere followers. Leibniz finds signs of this ambition in the fact that Descartes either concealed or downplayed the discoveries made by his predecessors and contemporaries in order to appear as an innovator (A VI.4.1486). This is related to his objection that Descartes dismissed erudite knowledge and scholarship of the past, an attitude that fostered the kind of self-satisfied ignorance displayed by his followers. Similar attacks were fairly common by the end of the century and figures prominently in Daniel Huet's repudiation of Descartes's philosophy in the Censura philosophiae cartesianae $(1689){ }^{6}$ 
Leibniz's polemic with Descartes and the Cartesians reaches its climax in 1697, after Claude Nicaise had circulated among Cartesians a letter from Leibniz dated February 15, in which he restates his accusation that Descartes leads to Spinozism. ${ }^{7}$ Leibniz concludes that "Spinoza only cultivated some seeds of Descartes's philosophy, so that it matters for the sake of religion of piety that this philosophy be castigated by subtracting the errors that are mixed with truth" (GP II.563). Régis took on Descartes's defense in the June issue of the Journal des sçavans. He claims that Descartes only meant that matter could (but would not) assume all possible forms. Moreover, Descartes had not rejected final causes altogether, but only their use in physics (where what is sought is not "why" things happen, but rather "how" they do happen) and still subscribed to them in moral philosophy (GP III.335-6). In reply, Leibniz defends himself from any bad intention and instead praises Descartes's genius and protests, somewhat disingenuously, that he had not intended to question Descartes's religious sincerity, but only to bring out the consequences of his doctrines. In particular, he argues that the passage from Principles III.47 entails not only necessitarianism but also eternal recurrence of the same events (GP IV.340-1).

From the preceding, it might look as if Leibniz was unambiguously setting his philosophical views against Cartesianism in those years. Yet his attitude toward Descartes and Cartesianism is more complex, and he displays a more conciliatory attitude in some of his published writings from the very same period. This is best illustrated in the "Système Nouveau", published in the July 1695 issue of the Journal des sçavans, which is the first published statement of Leibniz's own metaphysics. It is divided into two parts. The first part deals with the nature of substance, and in the account he presents 
substances are both principles of force and "true unities" conceived in analogy with the "I" or self and that confer substantiality upon aggregates (GP IV.483/WF 15). The second part deals with the "communication of substances", which covers the related problems of mind-body union and mind-body interaction. In both cases, Leibniz frames his views for a Cartesian audience. ${ }^{8}$ First, he assumes that mind and body are really distinct substances, whereas a core thesis of the ontology of substance set forth in the first part of the essay is that bodies considered in isolation from a soul, or a "true unity", are only aggregates and not substances. Furthermore, he takes the mind or the "I" or self as a paradigm of indivisible unity, which would naturally invite Cartesian readers to interpret his real unities in terms of a res cogitans (GP IV.483-4/WF 15). Third, he avoids imputing to Descartes a definite solution to the problem of mind-body interaction: "As far as we can see from his writings, M. Descartes gave up the game at this point" (GP IV.483/WF 16). Finally, he emphasizes the extent of his agreement with the occasionalist account of mind-body interaction endorsed by most Cartesians, namely the rejection of a real influence between mind and body. Thus Leibniz sides with occasionalism in his rejection of the account of causal interaction between distinct substances in terms of physical influence, an account that he considers to be unintelligible. Occasionalism, by contrast, is intelligible, but it transforms any case of everyday (mind-body as well as body-body) causation into a kind of miracle. Though Leibniz in the end did not accept occasionalism, he nevertheless presented this view as a step toward his own account, the pre-established harmony of mind and body according to which "God first created the soul, or any other real unity, in such a way that everything in it arises from its own nature, with a perfect 
spontaneity as regards itself, and yet with a perfect conformity to things outside it" (GP IV.484/WF 16-17).

The turn of the century signals a change in Leibniz's relation to the philosophy of Descartes. This period correspond to the decline of Cartesianism and to the rise of new philosophies, those of Locke and Newton in particular. Leibniz diagnoses a threat of materialism with Locke's hypothesis that matter suitably arranged might be endowed with the power of thinking and his skepticism with respect to the substantiality and immortality of the soul ${ }^{9}$. And he sees Newton's account of gravitation as an abandonment of the program of mechanical philosophy. Within this new outlook, Leibniz considered Descartes as an ally in his fight against materialism and the return to occult qualities (see Antibarbarus physicus, GP VII.337-39/AG 312-4). As one scholar aptly says, Leibniz is an inheritor of Descartes on the very project of a natural philosophy, whose aim is to give a view of the world grounded on an understanding of the nature of body and first causes. This sets him in sharp contrast with Newton, who continues the Galilean project of giving a quantitative description of the world instead of a causal explanation in terms of ultimate causes (Garber 2009: 179).

\section{Method and Epistemology}

Leibniz's most extensive examination of Descartes' philosophy is contained in the Animadversiones in partem generalem D. Cartesii ("Critical Thoughts on the General Part of Descartes' Principles"). The work must have been completed before mid-1692, when Leibniz gave a copy to Basnage de Beauval, in order that he circulate it among scholars in the Netherlands. He once envisaged the possible publication of this work as an 
appendix to a second edition of Huet's Censura. It turned out, however, that this second edition was published in 1694, while Basnage kept the manuscript with him until 1696, so that only a very small number of people actually read it, including Huygens, Bayle and Johann Bernoulli. These "critical observations on Descartes" (Letter to Huygens, 26 September 1696, GM II.146/L 416) provide the best entry to Leibniz's engagement with Descarte's epistemology, metaphysics and natural philosophy.

Cartesian doubt requires not only the suspension of belief with respect to what is doubtful or merely probable, but also its rejection as false (Meditations I, AT VII.22/CSM II.15). Leibniz criticizes this on two counts. First, he raises an epistemological objection, namely that this precept is not only useless but can lead us to adopt new prejudices ("Critical Thoughts", I.2, GP IV.355-56/L 384). As an example, Leibniz considers Descartes's reasoning in Principia I.8, where, from the certainty of his existence as a thinking thing and his ignorance of the existence of bodies, he concludes that the soul is not a corporeal thing. This reasoning is invalid but its plausibility derives from Descartes's decision to treat what is unknown or doubtful as false ("Critical Thoughts", I.8, GP IV.357-58/L 387). Moreover Descartes's precept presupposes that judgment and other doxastic attitudes depend on the will. Leibniz claims on the contrary that our judgments depend on reasons presented by the understanding, on which the will does not exert any direct control ("Critical Thoughts", I.6, GP IV.354/L 384; I.31-35;GP IV.361-2/L 387-8).

Besides this, Leibniz is critical of the radical doubt more generally. Evidence can be relied on without needing God's warrant, so that it is possible to attain certainty and knowledge in a particular field without knowing God, so that, pace Descartes, even an 
atheist may be a geometer. Conversely, the existence of God does not preclude our fallibility, due to the limitation of our minds. By contrast, once one adopts the general doubt strategy, the Cartesian circle is unavoidable ("Critical Thoughts", I.13, GP IV.358/L 385-6). Against the exclusion of merely probable knowledge (Discourse on Method, AT VI.31/CSM I.126-7), Leibniz claims that we should aim at maximizing the correspondence between the degree of assent and the weight of reasons, which requires the development of a theory of probability ("Critical Thoughts", I.1, GP IV.354/L 383-4; see also NE IV.xvi, 459-74 and IV.ii, 373).

Indeed, Leibniz admits the cogito as a first truth. But he downplays its importance by adding other "first truths" alongside it: the first truth of reason, i.e. the principle of contradiction, and several truths of fact:

There are as many primary truths of fact as there are immediate perceptions or if I may say so, consciousnesses [conscientiae]. However, I am conscious not only of myself thinking but also of my thoughts, and it is no more true and certain that I think than that this or that is thought by me. Hence the primary truths of fact can conveniently be reduced to these two: 'I think' and 'Various things are thought by me'. Whence it follows not only that I am, but that I am affected in various ways ("Critical Thoughts", I.7, GP IV.357/L 385; for an earlier statement of the same view, see the Letter to Foucher, 1675, A II. $1^{2} .388 /$ AG 2; GP IV.327; and NE IV.ii.1, 367).

Any primary truth of fact provides a ground on which it is possible to build further knowledge. Hence Descartes was mistaken in providing such a thin basis for our knowledge as the Cogito. 
More generally, the Cartesian method is flawed because Descartes had failed to find the genuine art of invention, or method (Letter to Elizabeth, 1678, A II.1.662/AG 236). Alternatively, he insinuates that Descartes actually found the method, but deliberately concealed it from his writings (A VI.4B.1484; GP IV.330; A II.2.535). Descartes's method, as embodied in the four precepts in the Discourse on Method, is both unnecessary and insufficient. The first rule, the so-called rule of evidence, according to which one should believe what one perceives clearly and distinctly, and the related general truth rule in Meditation Three that whatever is clearly and distinctly perceived is true (AT VII.35/CSM II.24), receive most of Leibniz's attention. As he had remarked in his "Meditations on Knowledge, Truth, and Ideas", published in 1684, without a criterion of clearness and distinctness, Descartes's rule is useless, because one could be deceived by the illusory certainty of her belief and mistakenly perceive what is obscure and confuse as clear and distinct (A VI.4.590/AG 26-27).

The a priori proof for God's existence provides a paradigmatic application of this objection to the evidence rule. According to Leibniz, Descartes's argument, though not invalid, is however incomplete. In one of his reconstructions, the argument runs like this (A VI.4.590/AG 26-7): ${ }^{10}$

1. Whatever is involved in the idea of $X$ can be predicated of $X$ or is a property of $X$.

2. The idea of the most perfect being (i.e. God) involves all perfections, including existence.

3. Therefore existence is a property of God (i.e. God exists). 
Although Leibniz challenges the argument on different grounds, he accepts some kind of inference from a thing's essence to its existence. But this granted, the argument remains inconclusive until one has proven that such an essence is possible. In the "Meditations" and elsewhere, Leibniz objects that Descartes is not entitled to assert (2) because nothing guarantees that our conception of what we mean by the name "God" corresponds to a true idea, unless one establishes that the notion of a most perfect being does not contain a contradiction. Otherwise, it may turn out that the notions we combine to form the notion of a most perfect being are incompatible and express an impossibility, just as with the notion of a greatest number or a fastest motion:

Similarly although I know what being is, and what it is to be the greatest and most perfect, nevertheless I do not yet know, for all that, whether there isn't a hidden contradiction in joining all that together, as there is, in fact, in the previously stated examples. In brief, I do not yet know, for all that, whether such a being is possible, for if it were not possible, there would be no idea of it. (Letter to Elizabeth 1678, A II.1.664-5/AG 238; see also A VI.3.462; Letter to Oldenburg, 28 December 1675, A II.1.393; and "Meditations on Knowledge", A VI.4.588/AG 25).

As a remedy to the limitations of Descartes's method, Leibniz relentlessly promotes the use of logic and the idea that the true method requires "arguments in form". This entails the rehabilitation of traditional logic, improved through his own various calculi and the finding of adequate symbolic expressions. The latter coincides with the project of developing a universal characteristic: 
I maintain that, in order to reason with evidence in all subjects, we must hold some consistent formalism. There would be less eloquence, but more certainty. But in order to determine the formalism that would do no less in metaphysics, physics, and morals, than calculation does in mathematics, that would even give us degrees of probability when we can only reason probabilistically, I would have to relate here the thoughts I have on a new characteristic (Letter to Elizabeth 1678, A II.1.666/AG 239; see also Critical Thoughts I.43-46, GP IV.363/L 389; I.75, GP IV.366/L 391).

Leibniz's views on method and knowledge are thus diametrically opposed to Descartes: to Descartes's view of knowledge as certain beliefs built upon the cogito alone, the rule of evidence and God's guarantee, he opposes an ideal of axiomatic knowledge, where some propositions are demonstrated from first truths or axioms, and, when no such demonstration is possible, propositions that are known with a certain degree of probability.

3. The Essence of Bodies and the Laws of Nature

Leibniz's early views on body and its laws are complex and their connection with Descartes, though critical on some points, does not become systematic until his own views are settled, sometime between 1676 and $1678^{11}$. In his 1669 letter to Thomasius, he holds that the essence of body consists in extension and impenetrability. But by 1671 he rejects this view and claims that its essence is motion (Letter to Arnauld, 1671, A II.1.278/L 149). He was also critical of Descartes's account of the laws of nature. Thus in a first set of critical remarks on the Principles of Philosophy from late 1675 or early 1676, 
Leibniz rejects the conservation of the quantity of motion and substitutes a law of the conservation of conatus, which he had established in his Theoria motus abstracti of 1671. But although his own basic laws disagree with Descartes's laws, actual bodies satisfy the latter, given the hypothesis of a plenum (A VI.3.213-7).

A decisive step occurs in late 1676 when, reflecting on Huygens' pendulum experiments, Leibniz formulates the fundamental principle of the equipollence of full cause and entire effect (the "Equipollence Principle") and realizes that the Cartesian laws violate this principle (A VI.3.584; De corporum concursu, Leibniz 1994: 145-6). The discovery of this principle coincides with a revision of the laws of motion and a rejection of Descartes's account of body (A VI.4.1988/L 278-9).

Leibniz rejects the very metaphysical ground of Descartes's physics: his account of the essence of body as extension (see Principles of Philosophy II.4, AT VIIIA.42/CSM I.224). First, extension is a complex concept, which, being resolvable in more primitive concepts (plurality, continuity and co-existence), cannot be the essence of body ("Critical Thoughts", I.52, GP IV.364/L 390; "On Body and Force, Against the Cartesians", GP IV.394/AG 251). Moreover, extension is a relative concept: it is necessarily the extension of some extended subject and for this reason it cannot constitute the essence of anything:

The nature of body does not consist in extension alone; in unraveling the notion of extension, I noticed that it is relative to something, which must be spread out, and that it signifies a diffusion or repetition of a certain nature. ... Extension is not an absolute predicate, but it is relative to that which is extended or diffused, and therefore it cannot be separated from the nature of that which is diffused anymore than a number can be separated from that which is counted ("On Body and Force, 
Against the Cartesians", GP IV.394/AG 251; see also Letter to De Volder, 30 June 1704, LDV 305; Conversation between Philarète and Ariste, GP VI.584/AG 261).

Finally, Leibniz does not accept the Cartesian view of substance. In particular, he rejects the independence criterion of substancehood on the ground that there are no bare substrata, so that every substance depends on having some modification or other ("Critical Thoughts", I.51; GP IV.364/389-90; see Descartes, Principles of Philosophy I.51, AT VIIIA.24/CSM I.210). He also rejects the identification of substance with its principal attribute, and the reduction of its essence to this principal attribute (Critical Thoughts, I.52; GP IV.364/L 390; Letter to De Volder, 31 December 1701, LDV 199; 20 June 1703, LDV 257; Conversation between Philarète and Ariste, GP VI.581-2/AG 258$60)$.

According to Leibniz, the essence of body consists not in extension, but in that which is diffused and constitutes extension. He identifies this with force, as it is defined within the new science of dynamics established in the early 1690's:

But since on our view, there is something besides matter in body, one might ask, what its nature is. Therefore, we say that it can consist in nothing but the dynamicon, or the innate principle of change and persistence (GP IV.394/AG 251).

Bodies, either the organic bodies of corporeal substances or mere aggregates, are endowed with derivative forces, which are the causes of motions studied in dynamics, or "that by which bodies actually act on one another or are acted upon by one another" ("A Specimen of Dynamics" [1695], GM VI.237/AG 120). Derivative active forces are either living forces (the force associated with a body in motion, its impetus) or dead forces (the forces associated with acceleration, as the centrifugal force and the force of gravity). 
Derivative passive force is twofold: impenetrability or antitypia and inertia or resistance to motion. These forces are characterized as temporary modifications of the primitive forces or alternatively as the expression at the level of phenomena of the underlying monads' primitive forces (Letter to De Volder, 20 June 1703, LDV 263).

This metaphysical framework is connected to a series of claims directly opposed to Descartes's views of body and its laws. (1) Force, or the cause of motion, is internal to bodies. (2) Moreover, the laws of motion are grounded in these forces. Finally, (3) force, and not quantity of motion, is conserved in motion. The first two claims are immediate consequences of Leibniz's view of substance as a spontaneous source of action, and are in direct opposition to occasionalism, which is sometimes presented by Leibniz as the natural development of Descartes's thesis that extension is the essence of corporeal substance $^{12}$.

Claim (3) constitutes Leibniz's central objection to the Cartesian account of the laws of nature. It is made public in the Brevis demonstratio erroris memorabilis $D$. Cartesii ("Short Demonstration of a Memorable Error by Mr. Descartes") published in 1686 in the Acta eruditorum. This paper was eventually translated into French and published in 1687 in the Nouvelles de la République des Lettres and triggered Leibniz's first controversy with French Cartesians - the Abbé Catelan and Denis Papin in particular - later called the vis viva or "living forces" controversy, on the nature of force and its correct measure, a controversy that lasted until the middle of the eighteenth century ${ }^{13}$. Against Descartes, Leibniz argues that: (i) living force must be conserved in motion; (ii) force is distinct from quantity of motion, defined as size times speed (understood as a 
scalar quantity, i.e. $m|v|$ ); and (iii) the correct measure of force is given by the product of size times the square of velocity $\left(m v^{2}\right) .^{14}$

That force needs to be conserved derives from the Equipollence Principle together with the definition of living force through its consumption in the production of an effect (as the height to which a body set in horizontal motion can be raised). Descartes wrongly thought that force and quantity of motion coincide, and his conservation law is inferred from an erroneous generalization from what holds in the special case of simple machines — inclined planes, levers and pulleys (A VI.4.2027/L 296). Leibniz first used an $a$ posteriori argument to establish the distinction between living force and quantity of motion and the estimation of force as $m v^{2}$ (DM, art. 17, A VI.4.1556-8; "Brief Demonstration", A VI.4.2028-30/L 296-8; "Critical Thoughts", II.36, GP IV.370-72/L 394-5). If, as Descartes maintains, force were measured by size times speed, that would entail the possibility of perpetual motion and a violation of the Equipollence Principle ("Dynamics: On Power and the Laws of Corporeal Nature", GM VI.204/AG 106). This argument rests crucially on the assumption of Galileo's law of free fall, which states that the velocity acquired by a falling body is equal to the square root of the height of fall.

This assumption was an issue in the controversy with the Cartesians opened up by the publication of the "Brief Demonstration" in 1686. According to Leibniz's Cartesian opponents, the Abbé Catelan and Denis Papin, Galileo's law cannot be generalized, because the behavior of heavy bodies depends on contingent features of our world, and in particular on the nature of the vortices surrounding Earth, which cause gravity. ${ }^{15}$ Another objection was that Leibniz had neglected time in his estimation of force. But once time is taken into account, force is proportional to velocity, not the square of velocity. This 
eventually led Leibniz to devise an a priori demonstration, which does not rest on any contingent assumptions and configuration of bodies, but on the distinction between force and action, defined as "the exercise of forces through time" (GP II.154/LDV 29) i.e. equal to the product of force by time. With the a priori demonstration, Leibniz thought he could directly derive the conservation of $m v^{2}$ from the Equipollence Principle.

Leibniz's criticism of Cartesian physics is not confined to the conservation principle, but extends to the collision rules and Descartes's account of impact (in Part Two of the Principles of Philosophy, AT VIII.A.62-70/CSM I.240-5). Descartes's third law has two parts: if body B collides with a stronger body C, it will rebound with its original speed (where a body's force is measured by its quantity of motion); but if B is stronger than $\mathrm{C}$, it will set $\mathrm{C}$ in motion and the two bodies will move in the same direction with the same global quantity of motion as before the collision. One of Leibniz's arguments is that Descartes's law of impact would have outcomes in which an effect is greater or smaller than its cause, in clear violation of the Equipollence Principle (GP III.45-46).

There are deep connections between the Leibnizian conservation principle and the critique of Descartes' law of impact on the one hand, and the nature of bodies on the other hand. Huygens had indeed established in 1669 that in the impact of hard bodies, like two pendulums, the product of size and square of the speed are the same before and after the collision (Huygens 1669: 928). But if two inelastic bodies (e.g., soft balls) of equal mass moving in opposite direction collide, motion seems to be entirely lost after impact. In order to generalize Huygens' results and guarantee the conservation of absolute force, and not just of directional force (i.e. quantity of motion in a given 
direction), Leibniz assumed that all bodies are elastic to some degree ${ }^{16}$. The apparent loss of living force after the collision of soft bodies is thus due to the fact that it is taken up by their internal parts and becomes insensible (GP II.169/LDV 71). The elasticity of all bodies is an essential assumption in Leibniz's physics and appears as early as the Hypothesis Physica Nova in 1671. It not only guarantees the conservation of absolute force, but in the late 1680 's Leibniz also appeals to elasticity as a model for understanding collision without causal transfer. Elasticity ensures that "bodies ... always gain their motion in collision from their very own force" (GP IV.397/AG 254; GP IV.486/AG 145; GM VI.240/AG 125; GM VI.251/AG 135; GP IV.515/AG 165). When two bodies collide, their own living forces are converted into an elastic force internal to each body, and when the body cannot be more deformed, this internal force is converted back into living force. Elasticity also entails that bodies are made up of smaller parts; hence the actual infinite division of matter and the rejection of atoms (GM VI.249/AG 132). Thus, in contrast with the Cartesians, Leibniz claims that there are no perfectly hard bodies, in the sense of bodies that cannot be deformed. Instead, all bodies have some degree of firmness and fluidity, which excludes Descartes's subtle matter as well as the second element, on account of their perfect uniformity (A VI.4.1627/LC 323; A VI.4.1988/LC 233; NE 125-6. See Descartes, Principles of Philosophy III.52, AT VIIIA.105). The elasticity assumption is justified indirectly, as a necessary requirement in order for the Equipollence principle and the Law of Continuity to hold (GP IV.399/AG 255).

By contrast, Descartes' law of impact and the seven collision rules specifying it entail violations of the Law of Continuity ("Critical Thoughts", II.40-44, GP IV.375/L 
397; "A Specimen of Dynamics", GM VI.248/AG 131). According to this principle "no change happens through a leap". More precisely, it says that when the difference between two cases continuously diminishes, the difference between their outcomes should diminish correspondingly (GP III.52-3/L 351-2). To illustrate, let us consider Descartes's first two rules, which concern the case of two bodies B and C moving with equal speed in opposite directions on the same line. According to rule 1, when B and C are equal, they rebound in their original direction with their original speed. But according to rule 2, when $\mathrm{B}$ is larger than $\mathrm{C}$, only $\mathrm{C}$ is reflected and $\mathrm{B}$ continues its motion in the same direction, both with the same speed as before. Thus a very small difference in B's size will produce radically different outcomes, contradicting the Law of Continuity.

Laws of nature thus depend crucially on some metaphysical principles, the Equipollence Principle and the Law of Continuity. Leibniz calls these principles "architectonic" because they are contingent and depend on God's wisdom and choice of the best possible world. As a result, the laws of nature are not metaphysically necessary but contingent, and they require God's wisdom. For this reason, laws of nature ultimately depend on final causes:

I have discovered ... that the laws of motion which are actually found in nature, and are verified by experience ... do not derive entirely from the principle of necessity, but from the principle of perfection and order; they are the effect of the choice and wisdom of God (Theodicy III.345, GP VI.319; see also letter to Rémond, 22 June 1715, GP III.645).

The principles of mechanics are themselves grounded in "more sublime principles, which show the wisdom of the Author in the order and perfection of his work" (Tentamen 
Anagogicum, GP VII.272/L 478). In turn, these laws of nature, as we have already said, need to be grounded in bodies, namely in their force, over and above extension and its modes, from which one may derive only necessary truths of geometry (DM art. 18, A VI.4.1558-9; "A Specimen of Dynamics", GM VI.242/AG 125).

4. Mind, Apperception and Animal Soul

According to Leibniz, Descartes's definition of thought entails that we must be always conscious of our thoughts (see Descartes, Principles of Philosophy I.9, AT VIIIA.7/CSM I.195; see also AT VII.160/CSM II.113 and AT VII.246/CSM II.246). Conversely, whatever lacks self-consciousness fails to have thoughts and since animals do not possess self-consciousness, they must lack souls. Leibniz denies both claims. He rejects the definition of thought as involving consciousness and defines perception instead as the "passing state that involves and represents a multitude in the unity or in the simple substance" ("Monadology", §14; GP VI.608/AG 214). This highlights a first difference with a Cartesian view of mind: for Leibniz, the mark of the mental is representationality, not consciousness. Consciousness or apperception is then defined as a kind of reflexive perception. ${ }^{17}$

Most importantly, whereas our soul is always thinking, apperception is not always present, thus making room for unconscious perceptions: "that is where the Cartesians have failed badly, since they took no account of the perceptions that we do not apperceive" ("Monadology", §14; GP VI.608/AG 214; see also "Principles of Nature and Grace", §4, GP VI.600/AG 208; GP III.307;657). Unconscious perceptions or "petites perceptions" 
are entailed by the fact that the mind is essentially active and must be always thinking. These unconscious perceptions are characterized thus:

At every moment there is in us an infinity of perceptions, unaccompanied by awareness or reflection; that is, of alterations in the soul itself, of which we are unaware because these impressions are either too minute and too numerous, or else too unvarying, so that they are not sufficiently distinctive on their own. But when they are combined with others they do nevertheless have their effect and make themselves felt, at least confusedly, within the whole (NE, Preface; 54)

These unconscious perceptions provide the best account of a wide range of cognitive and motivational phenomena, such as the experience of the sound of the sea (which requires that we have insensible perceptions corresponding to the noise caused by each individual wave), selective attention, our apparent indifference with respect to some choices. Another example is our emerging from a deep sleep. We would not be able to hear the alarm clock if we did not first have insensible perception of it (see NE, Preface; 54; "Monadology", §23, 610/AG 216). The latter case rests on the use of the Law of Continuity, which thus provides an a priori justification the existence of insensible perceptions (NE, Preface; 56-7). In virtue of this principle, our conscious perceptions must indeed come "by degrees from [perceptions] that are too minute to be noticed" (NE, Preface; 57; see also NE II.i.15-19, 116-118). By contrast, the Cartesian view of mind fails to satisfy the law of continuity, just as the Cartesian account of the laws of impact fails to do with respect to bodies ${ }^{18}$.

In addition, Leibniz attributes souls to animals. Until the late 1670 s, when he rehabilitated substantial forms, Leibniz considers animals as mere machines (see for 
instance the Letter to Conring, 19/29 March 1678, A II.1.606/L 190). But in the late 1680s he begins to reject the Cartesian view and considers it to be highly probable that animals have souls (see Discourse on Metaphysics, art. 34; A VI.4.1583/AG 65, and Letter to Arnauld, 30 April 1687, A II.2.172/AG 87-8; see also AG 104 and GP IV.479/AG 139). However, his interest in the question of animal souls was steered by the article "Rorarius" in the first edition of Bayle's Dictionary (1697), which contains both objections to the Cartesian thesis and a critical discussion of Leibniz' own system. In opposition to Descartes, Leibniz assumes the impossibility of explaining any kind of perception at all, including sensation, on the basis of extended matter and its properties. ${ }^{19}$ The reason is that perception is defined either as the expression within a unity or as an internal action. From this it follows that it can only arise in a simple, active, hence immaterial being (A II.1.860-1; GP VII.328-9/SLT 64-5; "Monadology", §17, GP VI.609/AG 215). As a result, either animals are mere machines lacking perception, or else they have perceptions and hence must have souls. The fact of animal perception is then inferred by analogy with human perception, allowing the conclusion that animals have immaterial souls (GP VII.329/SLT 64).

But Leibniz also has a more direct argument, based on the premise that entelechies or active forces are necessarily endowed with perceptions. Since there must be such entelechies everywhere in matter, the argument concludes that there is perception everywhere in matter. This argument attributes perception far beyond the realm of animals, including all living beings. But even if animals have indestructible souls just as human beings, they still differ insofar as animal souls lack rationality and deductive reasoning. Moreover Leibniz conjectures that while human souls remain self-conscious 
after death, as a requisite for their personal identity, when animals die, their souls lose any kind of conscious perceptions (GP VII.330-1/SLT 65). The debate over the Cartesian doctrine of the animal machine involves a far more extensive disagreement about the entities populating the material world. Far from being merely res extensae, this world is full of enduring souls, always endowed with perceptions of the universe (Letter to Bernoulli, 7 January 1697, A III.7, 245). But most of these souls are "mere monads", devoid of conscious perceptions. Only some of them, the animal souls, have sensations or conscious perceptions, and among the latter, only the rational minds or spirits are capable of rational thought and consciousness of the I or self (see GP VII.529-31; 535;

"Monadology", §19-29, AG 215-7).

\section{Conclusion}

Three issues stand out from this discussion: evidence, final causes, and continuity. According to Leibniz, Descartes's errors in his account of knowledge, metaphysics, natural philosophy and philosophy of mind can be traced back either to his overconfidence in the value of evidence or to his failure to recognize the role of final causes and the Law of Continuity. This is why Descartes was only the Antechamber of truth for Leibniz.

\section{REFERENCES}

Adams, Robert M. (2004), Leibniz: Determinist, theist, idealist, New York: Oxford University Press. 
Antognazza, Maria Rosa (2009), Leibniz: An Intellectual Biography, Cambridge: Cambridge University Press.

Belaval, Yvon (1962), Leibniz, critique de Descartes, Paris: Gallimard.

Bouillier, Francisque (1868), Histoire de la philosophie cartésienne, 2 vols. Paris: Delagrave.

Brown, Gregory (1984), “'Quod ostendendum susceperamus': What did Leibniz undertake to Show in the Brevis Demonstratio?" in Albert Heinekamp (ed.), Leibniz' Dynamica, Stuttgart: Steiner, 122-37.

Catelan, François de (1686), “Courte Remarque de M. l'Abbé D.C.”, Nouvelles de la République des Lettres 8: 1000-5.

Cottingham, John (1978), ““A Brute to the Brutes?': Descartes' Treatment of Animals”, Philosophy 53 (206): 551 - 559.

Cover, Jan A. and Donald P. Rutherford (eds.) (2005), Leibniz: Nature and Freedom, Oxford: Oxford University Press.

Garber, Daniel (1995), "Leibniz: Physics and Philosophy”, in Nicholas Jolley (ed.), The Cambridge Companion to Leibniz, Cambridge: Cambridge University Press, 270352.

Garber, Daniel (2009), Leibniz: Body, Substance, Monad, New York: Oxford University Press.

Griffin, Michael (2013), Leibniz, God and Necessity, Cambridge: Cambridge University Press.

Huet, Pierre-Daniel (1689), Censura philosophiae cartesianae, Paris: Daniel Horthemels. Iltis, Carolyn (1971), "Leibniz and the Vis Viva Controversy" Isis 62: 21-35. 
Jorgensen, Larry M. (2009), “The Principle of Continuity and Leibniz's Theory of Consciousness", Journal of the History of Philosophy 47: 223-48.

Knobloch, Eberhard (2006), "Beyond Cartesian limits: Leibniz's passage from algebraic to "transcendental" mathematics", Historia Mathematica, 33: 113-131

Laerke, Mogens (2008), Leibniz lecteur de Spinoza. La genèse d'une opposition complexe, Paris: Champion.

Mogens Laerke (2013), "Ignorantia inflat Leibniz, Huet, and the Critique of the Cartesian Spirit", The Leibniz Review 23: 13-42.

Leibniz, Gottfried Wilhelm (1854), Réfutation inédite de Spinoza, ed. Louis Alexandre Foucher de Careil, Paris.

Leibniz, Gottfried Wilhelm (1849-63), Leibnizens Mathematische Schriften, ed. C. I. Gerhardt, 7 vols., Berlin: Asher and Schmidt; reprint Hildesheim: G. Olms, 1971 [GM].

Leibniz, Gottfried Wilhelm (1875-90), Die Philosophischen Schriften von G.W. Leibniz, ed. C. J. Gerhardt, 7 vols., Berlin: Weidemann; reprint Hildesheim: G. Olms, 1960 [GP].

Leibniz, Gottfried Wilhelm (1890), The Philosophical Works of Leibniz, ed. and trans. W. Duncan, New Haven: Yale University Press.

Leibniz, Gottfried Wilhelm (1923 - ), Sämtliche Schriften und Briefe, Darmstadt, Leipzig and Berlin: Akademie der Wissenschaften. Cited by series, volume and page number $[\mathrm{A}]$.

Leibniz, Gottfried Wilhelm (1952), Theodicy, trans. E. M. Huggard, New Haven: Yale University Press. 
Leibniz, Gottfried Wilhelm (1969), Philosophical Papers and Letters, trans. and ed. Leroy E. Loemker, Dordrecht: D. Reidel [L].

Leibniz, Gottfried Wilhelm (1989), Philosophical Essays, trans. and ed. Roger Ariew and Daniel Garber, Indianapolis: Hackett [AG].

Leibniz, Gottfried Wilhelm (1996), New Essays on the Human Understanding, trans. Jonathan Bennett and Peter Remnant, Cambridge: Cambridge University Press [NE]. Cited by page number in A VI.6.

Leibniz, Gottfried Wilhelm (1994), De corporum concursu, ed. M. Fichant, La réforme de la dynamique. De corporum concursu (1678) et autres textes inédits, Paris: Vrin. Leibniz, Gottfried Wilhelm (1997), Leibniz's 'New System' and Associated Contemporary Texts, R.S. Woolhouse and Richard Francks (eds. and trans.), Oxford: Oxford University Press [WF].

Leibniz, Gottfried Wilhelm (2001), The Labyrinth of the Continuum. Writings on the Continuum Problem, 1672-1686, trans. and ed. Richard Arthur, New Haven: Yale University Press [LC].

Leibniz, Gottfried Wilhelm (2006), The Shorter Leibniz Texts: A Collection of New Translations, trans. and ed. Lloyd Strickland, London: Continuum [SLT].

Leibniz, Gottfried Wilhelm (2013), The Leibniz-De Volder Correspondence. With Selections from the Correspondence between Leibniz and Johann Bernoulli, trans. and ed. Paul Lodge, New Haven: Yale University Press [LDV].

Levey, Samuel (2005), "Leibniz on Precise Shapes and the Corporeal World", in Cover \& Rutherford 2005: 69-94. 
Locke, John (1975) An Essay concerning Human Understanding, ed. P.H. Nidditch, Oxford: Clarendon.

Nadler, Steven M. (2011), “Consciousness Among the Cartesians” Studia Leibnitiana 43: $132-144$.

Papin, Denis (1691), “Mechanicorum de viribus motricis sententia assertata a Dn. Papino adversus Cl. G. G. L.”, Acta eruditorum: 183-88.

Papineau, David (1977), “The Vis Viva Controversy”, Studies in History and Philosophy of Science 8: 111-42.

Phemister, Pauline (2005), Leibniz and the Natural World: Activity, Passivity and Corporeal Substances in Leibniz's Philosophy, Dordrecht: Springer.

Phemister, Pauline (2011), "Descartes and Leibniz" in Brandon Look (ed.) (2011), The Continuum Companion to Leibniz, London: Continuum, 16-31.

Simmons, Alison (2001), "Changing the Cartesian Mind: Leibniz on Sensation, Representation and Consciousness”, The Philosophical Review, 110: 31-75. 
${ }^{1}$ Belaval 1962 is the classic study on Leibniz and Descartes. For a more recent study, see Phemister 2011. Leibniz's alleged Cartesianism is embodied in Victor Cousin's claim that Leibniz was "three-quarters a Cartesian". This was corrected by Bouillier, who saw Leibniz as both an opponent and a disciple of Descartes; see Bouillier 1867: II.405. Some important issues will not be envisaged in this chapter, mathematics in particular. On this, see Belaval 1962. For a more recent study, see Knobloch 2006.

${ }^{2}$ On Leibniz's encounter with Cartesians in Paris and his access to Descartes's manuscripts, see Antognazza 2009: ch.3, especially p.167.

${ }^{3}$ On the importance of this reading in the evolution of Leibniz' relation to Spinoza and Descartes, see Laerke 2008: 558-850.

${ }^{4}$ Two Sects of Naturalists, A VI.4.1385/AG 282. See Cover and Rutherford 2005: 5.

${ }^{5}$ Leibniz's early writings show a commitment to the view that everything happens necessarily as a consequence of God's necessary goodness. See Letter to Wedderkopf, May 1671, A II.1.186-7/L 146-7. After 1676 however, Leibniz seems to think that final causes and objective values actually require genuine contingency, so that God's necessary goodness no longer entails the world's necessary existence. See in particular A VI.3.582; A VI.4.1447/AG 20-21, and Theodicy §173. For commentary, see Adams 1994. Griffin (2013: chap.3) holds the view that only blind necessity is incompatible with moral responsibility and final causes.

${ }^{6}$ See in particular Huet 1689: 197-202. In connection with Leibniz, see Laerke 2013 and Laerke 2015: 313-22. See also A II.1.776-77/AG 241-45; A VI.4.2047-51, 2057-65; GP IV.337. 
${ }^{7}$ On the controversy, see (Laerke 2013).

${ }^{8}$ In the 26 August 1714 letter to Rémond, Leibniz is explicit that he uses distinct language in distinct journals: "In the Leipzig journal [Acta Eruditorum] I adapt myself to the language of the schools, in the others I adapt myself more to the style of Cartesians" (GP III.624/WF 1, n.3); see Phemister 2005: ch.1.

${ }^{9}$ See Locke 1975: IV, vi, §3.

${ }^{10}$ See also Quod ens perfectissimum existit, A VI.3.578/L 167; Letter to Eckhard 1677, A II.1.498-502/L 321-23; Letter to Elizabeth 1678, A II.1.664-65/AG 238; GP IV.401-6; GP VII.490. For detailed analysis, see Adams 1994: part II and Griffin 2013. Leibniz's preferred version of the argument dispenses with the notion of perfect being, our idea of God and the Cartesian predication principle that figures as premise (1) of our reconstruction and infer directly from the possibility of a necessary being to its actual (and necessary) existence ("Critical Thoughts", I.14, GP IV.358-9/L 386).

${ }^{11}$ For an overview of the metaphysical foundations of Leibniz's physics, see in particular Garber 1995 and 2009.

${ }^{12}$ Leibniz argues furthermore that occasionalism leads to Spinozism; See GP IV.508/AG 159-60; GP IV.515/AG 165; GP IV.396-7/AG 253-4; GP IV.567-8/L 583; GM

VI.242/AG 125; Theodicy $\$ 393$.

${ }^{13}$ Catelan 1686 and Papin 1691. On the controversy, see Iltis 1971 and Papineau 1981.

${ }^{14}$ See Brown 1984, Garber 1995, and Garber 2009: 144-55.

${ }^{15}$ See Garber 1995:313.

${ }^{16}$ See GP III.56-7 and the Letter to Huygens, 26 September 1692, A II.2.581-2/L 415-6.

On elasticity and its role in Leibniz's dynamics, see Garber 1995: 321-5. 
${ }^{17}$ For the role of reflection and an interpretation of apperception as a kind of higher order representation, see Simmons 2001. For a recent account of consciousness in Descartes and the Cartesians, see Nadler 2011.

${ }^{18}$ See Jorgensen 2009.

${ }^{19}$ Compare Descartes's letter to Mersenne, 11 June 1640 (AT III.85/CSMK 148) with his letter to Henry More, 5 February 1649 (AT V.276/CSMK 365). The view that Descartes ascribes at least feelings to animals is advocated by Cottingham 1978. 